\title{
Spastic paraplegia due to recessive or dominant mutations in ERLIN2 can convert to ALS
}

Maria-Del-Mar Amador, MD, MSc, François Muratet, MSc, Elisa Teyssou, PhD, Guillaume Banneau, PhD, Véronique Danel-Brunaud, MD, MSc, Etienne Allart, MD, PhD, Jean-Christophe Antoine, MD, Jean-Philippe Camdessanché, MD, PhD, Mathieu Anheim, MD, PhD, Gabrielle Rudolf, PhD, Christine Tranchant, MD, Marie-Céline Fleury, MD, Emilien Bernard, MD, MSc, Giovanni Stevanin, PhD, and Stéphanie Millecamps, PharmD, PhD

Neurol Genet 2019;5:e374. doi:10.1212/NXG.0000000000000374

\section{Abstract}

\section{Objective}

The aim of this study was to evaluate whether mutations in ERLIN2, known to cause SPG18, a recessive hereditary spastic paraplegia (SP) responsible for the degeneration of the upper motor neurons leading to weakness and spasticity restricted to the lower limbs, could contribute to amyotrophic lateral sclerosis (ALS), a distinct and more severe motor neuron disease (MND), in which the lower motor neurons also profusely degenerates, leading to tetraplegia, bulbar palsy, respiratory insufficiency, and ultimately the death of the patients.

\section{Methods}

Whole-exome sequencing was performed in a large cohort of 200 familial ALS and 60 sporadic ALS after a systematic screening for C9orf72 hexanucleotide repeat expansion. ERLIN2 variants identified by exome analysis were validated using Sanger analysis. Segregation of the identified variant with the disease was checked for all family members with available DNA.

\section{Results}

Here, we report the identification of ERLIN2 mutations in patients with a primarily SP evolving to rapid progressive ALS, leading to the death of the patients. These mutations segregated with the disease in a dominant (V168M) or recessive (D300V) manner in these families or were found in apparently sporadic cases (N125S).

\section{Conclusions}

Inheritance of ERLIN2 mutations appears to be, within the MND spectrum, more complex that previously reported. These results expand the clinical phenotype of ERLIN2 mutations to a severe outcome of MND and should be considered before delivering a genetic counseling to ERLIN2-linked families.

\author{
Correspondence \\ Dr. Millecamps \\ stephanie.millecamps@upmc.fr
}




\section{Glossary}

ALS = amyotrophic lateral sclerosis; IDMDC = intellectual disability, motor dysfunction, and joint contractures; HSP = hereditary spastic paraplegia; $\mathbf{M N D}=$ motor neuron disease; $\mathbf{S P}=$ spastic paraplegia; $\mathbf{U L}=$ upper limb; VUS = variant of unknown significance.

Amyotrophic lateral sclerosis (ALS) and hereditary spastic paraplegia (HSP) are 2 distinctive degenerative motor neuron diseases (MNDs). HSP is a slow progressing disease usually starting in childhood or young adulthood. Its common feature is the degeneration of the upper motor neurons leading to weakness and spasticity restricted to the lower limbs. In ALS, and some complex forms of HSP, the lower motor neurons are also affected. ALS leads to a mostly rapidly progressive paralysis of the 4 limbs, bulbar area, and respiratory muscles, typically beginning in the sixth to seventh decade of life, with a median survival of 2-4 years after onset of disease. Disease progression is slower in HSP and is dependent of associated clinical signs. Homozygous nullimorphic deletion/frameshift mutation or compound heterozygous splice site/missense mutations in endoplasmic reticulum lipid raft-associated protein 2 (ERLIN2) have been identified as a cause of SPG18, a form of HSP, juvenile primary lateral sclerosis, and a neurologic disorder termed "intellectual disability, motor dysfunction, and joint contractures (IDMDC)" all being neurodegenerative diseases of the upper motor neuron with onset in early childhood. $^{1-3} \mathrm{~A}$ dominant form of pure HSP was recently reported to be caused by a heterozygous mutation in ERLIN2, which underlines the complexity of the ERLIN2 mutation in spastic paraplegia (SP) phenotype. ${ }^{4}$ Here, we described ERLIN2 mutations segregating with MND in 2 pedigrees affecting patients with HSP evolving to rapid progressive ALS.

\section{Methods}

\section{Standard protocol approvals, registrations, and patient consents}

All patients signed a consent form for the genetic research. Protocols were approved by the Medical Research Ethics Committee of "Assistance Publique Hôpitaux de Paris." The diagnosis of ALS and SP was based on the published criteria as previously described. ${ }^{5}$

\section{Genetic screening}

This patient cohort (including 200 familial and 60 sporadic cases) were screened for $\mathrm{C} 9$ orf $72 .{ }^{5}$ Then whole exome sequencing was performed using classical procedures. Exons were captured on the genomic DNA using the SureSelect Clinical Research Exome $50 \mathrm{Mb}$ kit (Agilent), followed by massive parallel sequencing on a Hiseq 2000 sequencer (Illumina) at Integragen (Evry, France). The Burrows-Wheeler algorithm was used to align the $100 \mathrm{bp}$ length paired-end reads to the hg 38 version of the human genome (Ensembl); variants were called using the Genome Analysis Toolkit software. Data were imported into the SIRIUS (sirius. integragen.com) database for further analysis. This database was interrogated for 30 ALS-related genes (including ALS2, ANG, ANXA11, CCNF, CHCHD10, DAO, DCTN1, FIG4, FUS, GLE1, GLT8D1, HNRNPA1, HNRNPA2B1, KIF5A, MATR3, NEK1, OPTN, PFN1, SETX, SIGMAR1, SOD1, SQSTM1, SS18L1, TARDBP, TBK1, TIA1, TUBA4A, UBQLN2, VAPB, and VCP) and $70 \mathrm{SP}$ genes ${ }^{6}$ to select variants with a minor allele frequency $<0.005 \%$ in Single Nucleotide Polymorphism Database, HapMap, 1000 Genomes, Exome Variant Server, and gnomAD databases. ERLIN2 variants were validated using Sanger analysis with BigDye chemistry as recommended by the supplier (Applied Biosystems). Segregation of the identified variant with the disease was checked for all family members with available DNA.

\section{Data availability}

Anonymized data are available from the corresponding author upon reasonable request.

\section{Clinical findings}

In ALSSP1 pedigree, 2 second-degree cousins were diagnosed with ALS according to the Awaji criteria at ages 57 years (IV1) and 65 years (IV2), respectively (figure, A). The site of onset of lower MND was either the upper limbs (UL) for IV1 or bulbar and UL (IV2). Death occurred 12-18 months later due to restrictive respiratory insufficiency. Both had SP beginning 20 (IV2) to 32 years (IV1) before ALS onset. IV3 presented HSP from age 32 years, without signs of peripheral motor neuron dysfunction to date. In ALSSP2 pedigree, 2 brothers developed definite ALS at ages 54 (III2) and 59 (III4) years, respectively, both of bulbar and UL onset, occurring 38-39 years after HSP diagnosis (figure, B). ALS disease was rapidly progressive with an ALS Functional Rating Scale-Revised (ALSFRS-R) score ratio ${ }^{8}$ of 2.25 (III2) and 3.66 (III4), respectively (table 1). Their sister had mental retardation and typical HSP starting at age 15 years. An apparently sporadic subject developed SP at age 45 years, and then converted to ALS of UL and bulbar onset at age 66 years. ALS disease was also rapid progressive (ALSFRS-R ratio 1.41) with death occurring 20 months after conversion to ALS. A last patient, previously healthy, developed typical spinal ALS of UL onset at age 45 years. During disease course, notorious spasticity of the lower limbs was noted. He died 4 years after disease onset. His mother had died of bulbar ALS 5 years after first symptom onset (ALSSP3).

\section{Genetic findings}

A heterozygous ERLIN2 c.502G>A, p.Val168Met (V168M) mutation was found in ALSSP1 pedigree, cosegregating with disease and accounting for the autosomal dominant form of MND in this family. In pedigree ALSSP2, a homozygous ERLIN2 c.899A >T, p.Asp300Val (D300V) mutation was recessively transmitted. Another variant c.374A $>$ G, p.Asn 125 Ser (N125S) was found in the isolated case. A last ERLIN2 variant 
Figure Identification of ERLIN2 mutations in patients with ALS

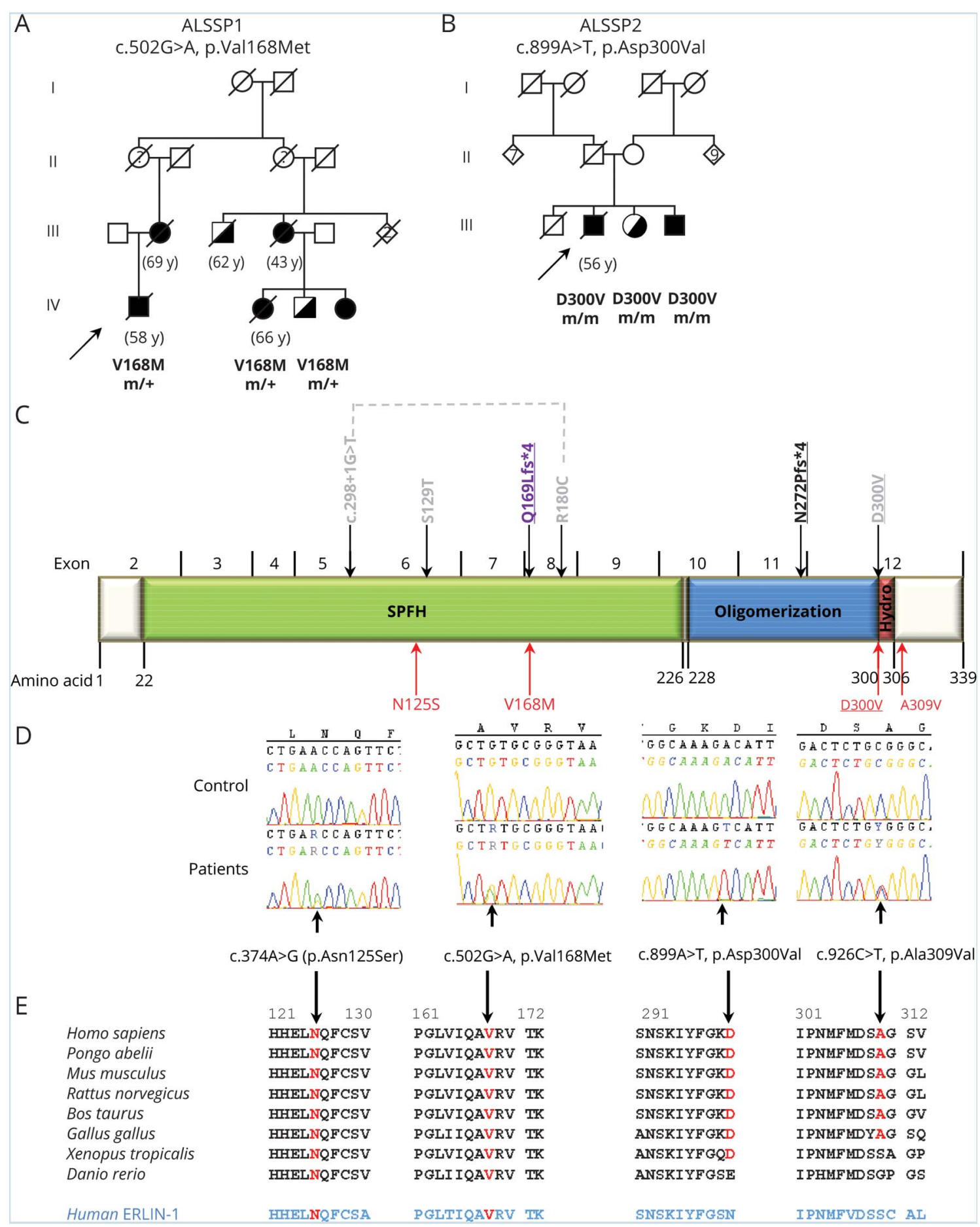

Pedigrees of the ALSSP1 and ALSSP2 families with the heterozygous V168M (A) and homozygous D300V (B) mutations. Arrows indicate index patients. When available, the age at death (in brackets) is indicated above the symbol representing the patients. Black fill: ALS case; black half fill: SP case. The genotypes are indicated using a single letter amino acid code below the index case and some relatives for whom DNA was available ( $\mathrm{m} /+$ : heterozygous, $\mathrm{m} / \mathrm{m}$ : homozygous). (C) Representation of Erlin-2 protein domains with the position of the amino acid substitutions previously reported in spastic paraplegia (gray), juvenile primary lateral sclerosis (purple), intellectual disability, motor dysfunction, and multiple joint contractures (black). Mutations identified in patients with ALS in the present study are in red. Full underline, homozygous mutations; dotted line, compound heterozygous mutation. SPFH, stomatins, prohibitins, flotillins, and $\mathrm{HfIK/C}$ domain (green); Oligomerization domain (blue); hydro, hydrophobic patch (orange). Data are compiled from references 1, 2, 3, 4, 6, 7. (D) Part of chromatograms showing the N125S (exon 6), the V168M (exon 8), the D300V, and the A309V (exon 12) variants pointed by an arrow (in patients) and the corresponding normal sequences (in control). (E) Sequence alignments of part of the Erlin-2 amino acids from diverse species using MultAlin web site. The positions of the Asn125, Val168, Asp300, and Ala309 (pointed by an arrow) are in red. Sequences used include Homo sapiens (NP 009106.1), Pongo abelii (NP 001126372.1), Mus musculus (NP_705820.1), Rattus norvegicus (NP_001099558.1), Bos taurus (NP_001040041.1), Gallus gallus (XP_424380.1), Xenopus tropicalis (NP_001016719.1), and Danio rerio (NP_001121887.1). Human Erlin-1 amino acid sequence is also indicated in blue (NP_001094096.1). ALS = amyotrophic lateral sclerosis; SP = spastic paraplegia. 
Table 1 Clinical features of patients harboring ERLIN2 mutations

\begin{tabular}{|c|c|c|c|c|c|c|c|c|c|c|c|c|}
\hline Variant & Pedigree & $\begin{array}{l}\text { Disease } \\
\text { inheritance }\end{array}$ & Patients & $\begin{array}{l}\text { Age at SP } \\
\text { onset, y }\end{array}$ & $\begin{array}{l}\text { SP duration } \\
\text { without ALS, y }\end{array}$ & Remarks & $\begin{array}{l}\text { Age at ALS } \\
\text { diagnosis }\end{array}$ & $\begin{array}{l}\text { Site of ALS } \\
\text { onset }\end{array}$ & $\begin{array}{l}\text { ALS } \\
\text { duration, } \\
\text { mo }\end{array}$ & $\begin{array}{l}\text { ALSFRS-R } \\
\text { (score ratio) }\end{array}$ & $\begin{array}{l}\text { Diaphragmatic } \\
\text { dysfunction }\end{array}$ & $\begin{array}{l}\text { Age at } \\
\text { death, } y\end{array}$ \\
\hline \multirow[t]{3}{*}{ V168M } & ALSSP1 & $\begin{array}{l}\text { Autosomal } \\
\text { dominant }\end{array}$ & IV1 & 25 & 32 & & 57 & UL & 12 & ND & Present & 58 \\
\hline & & & IV2 & 45 & 20 & & 65 & $\begin{array}{l}\text { Bulbar and } \\
\text { UL }\end{array}$ & 18 & ND & Present & 66 \\
\hline & & & IV3 & 32 & $>30$ & & NA & NA & NA & NA & Absent & NA \\
\hline \multirow[t]{3}{*}{ D300V } & ALSSP2 & $\begin{array}{l}\text { Autosomal } \\
\text { recessive }\end{array}$ & 1112 & 16 & 38 & & 54 & $\begin{array}{l}\text { Bulbar and } \\
\text { UL }\end{array}$ & 18 & 2.25 & Present & 56 \\
\hline & & & 1113 & 15 & $>44$ & $\begin{array}{l}\text { Mental } \\
\text { retardation }\end{array}$ & NA & NA & NA & NA & Absent & NA \\
\hline & & & 1114 & 20 & 39 & & 59 & $\begin{array}{l}\text { Bulbar and } \\
\text { UL }\end{array}$ & $>12$ & 3.66 & ND & NA \\
\hline A309V & ALSSP3 & $\begin{array}{l}\text { Autosomal } \\
\text { dominant }\end{array}$ & IIII & NA & NA & & 45 & UL & 46 & ND & Present & 49 \\
\hline N125S & ALSSP4 & $\begin{array}{l}\text { Apparently } \\
\text { sporadic }\end{array}$ & II1 & 20 & 45 & & 66 & $\begin{array}{l}\text { Bulbar and } \\
\text { UL }\end{array}$ & 20 & 1.41 & Present & 67 \\
\hline
\end{tabular}

Abbreviations: ALS = amyotrophic lateral sclerosis; NA = not applicable; ND = not determined; SP = spastic paraplegia; UL = upper limb. 
Table 2 Pathogenicity prediction tests for ERLIN2 mutations

\begin{tabular}{|c|c|c|c|c|c|c|c|}
\hline Mutations & SIFT & PolyPhen-2 (score) & $\begin{array}{l}\text { CADD Phred } \\
\text { score }\end{array}$ & $\begin{array}{l}\text { Mutation } \\
\text { taster }\end{array}$ & Panther & MAF in gnomAD & dbSNP \\
\hline $\begin{array}{l}\text { c.374A>G, } \\
\text { p.Asn125Ser }\end{array}$ & Deleterious & $\begin{array}{l}\text { Probably damaging } \\
(0.997)\end{array}$ & 26.5 & $\begin{array}{l}\text { Disease } \\
\text { causing }\end{array}$ & $\begin{array}{l}\text { Probably } \\
\text { damaging }\end{array}$ & Absent & Absent \\
\hline $\begin{array}{l}\text { c.502G>A, } \\
\text { p.Val168Met }\end{array}$ & Deleterious & $\begin{array}{l}\text { Probably damaging } \\
\text { (0.999) }\end{array}$ & 32 & $\begin{array}{l}\text { Disease } \\
\text { causing }\end{array}$ & $\begin{array}{l}\text { Probably } \\
\text { damaging }\end{array}$ & Absent & Absent \\
\hline $\begin{array}{l}\text { c.899A }>\mathrm{T}, \\
\text { p.Asp300Val }\end{array}$ & Deleterious & $\begin{array}{l}\text { Probably damaging } \\
(0.982)\end{array}$ & 28.8 & $\begin{array}{l}\text { Disease } \\
\text { causing }\end{array}$ & $\begin{array}{l}\text { Probably } \\
\text { damaging }\end{array}$ & $\begin{array}{l}\text { All: } 0.0008 \% \\
\text { NFE: } 0.0018 \%\end{array}$ & rs763958615 \\
\hline $\begin{array}{l}\text { c.926C }>\text { T, } \\
\text { p.Ala309Val }\end{array}$ & Tolerated & Benign (0.001) & 10.76 & $\begin{array}{l}\text { Disease } \\
\text { causing }\end{array}$ & $\begin{array}{l}\text { Possibly } \\
\text { damaging }\end{array}$ & $\begin{array}{l}\text { All: } 0.0020 \% \text { NFE: } \\
0.0035 \%\end{array}$ & rs780065091 \\
\hline
\end{tabular}

Abbreviations: $\mathrm{CADD}=$ Combined Annotation-Dependent Depletion; dbSNP = Single Nucleotide Polymorphism Database; $\mathrm{MAF}=$ minor allele frequency; NFE $=$ Non-Finnish European.

Five software packages investigating in silico pathogenicity have been used to classify variants from benign (tolerated) to disease causing (deleterious, probably damaging). A variant with a CADD score $>20$ indicates that it is among the $1 \%$ most deleterious variants in the genome and $>30$ among the $0.1 \%$. MAF in control populations and dbSNP identification number are also indicated.

c.926C > T, p.Ala309Val (A309V) was identified in the ALSSP3 familial index case (figure, $\mathrm{C}$ and $\mathrm{D}$ ).

No other variant in the main ALS- or HSP-related genes was identified in these individuals. All but 1 variant were predicted to be deleterious by 5 in silico algorithms (table 2). As A309V variant was predicted to be less pathogenic than the other ones and affects a less conserved amino acid across species and paralogs, it could rather be considered as a variant of unknown significance. In contrast, the 2 other variants dominantly transmitted (N125S and $\mathrm{V} 168 \mathrm{M})$ are located in the stomatins, prohibitins, flotillins and $\mathrm{HflK} / \mathrm{C}$ domain of Erlin-2 protein, affect residues that are conserved up to the zebrafish in Erlin-2 sequence, are conserved in human Erlin-1 sequence too (figure, E), and remain absent from control databases, suggesting that they are highly pathogenic.

\section{Discussion}

A genetic overlap has been previously described for various MNDs: recessive mutations in ALS2 and SPG11 have been identified in patients with HSP or slowly progressive juvenileonset ALS. ${ }^{9}$ Recessive mutations in SPG11 are also responsible for CMT2. ${ }^{9}$ Dominant mutations in KIF5A can lead to HSP, CMT2, or ALS depending on the protein domain they affect. ${ }^{10}$ Here, we report the identification of ERLIN2 mutations in patients with a primarily SP evolving to severe ALS phenotype. It is to note that 3 of the 12 patients reported with IDMDC died between ages 18 and 23 years, albeit the cause of these premature deaths was not detailed. ${ }^{3}$ Among the mutations we identified, 3 (N125S, V168M, and $\mathrm{A309V}$ ) are novel, and the last one (D300V) was already identified in a consanguineous family of Portuguese origin with pure HSP. ${ }^{6}$ These mutations segregated with the disease in a dominant $(\mathrm{V} 168 \mathrm{M})$ or recessive $(\mathrm{D} 300 \mathrm{~V})$ manner underlying the complexity of ERLIN2 mutation inheritance along the MND spectrum. Such an SP to ALS switch has recently been described for the dominant X-linked UBQLN2 ALS-related gene, ${ }^{5}$ and our present results added ERLIN2 as a candidate gene for this form of
MND. The mean disease duration before conversion of the phenotype ranged from 20 to 45 years and seemed to be increased when SP disease onset occured earlier. The severe prognosis of ALS complicates the genetic counseling delivered to these SP families. Some affected members of the families we described remain to date with SP phenotype, suggesting that modifier genes could also intervene in the worsening of the motor phenotype.

Erlin-2 is involved in the endoplasmic reticulum-associated degradation pathway of inositol 1,4,5-trisphosphate receptors (IP3Rs) through ubiquitination and the regulation of cellular cholesterol homeostasis. The homozygous null allele identified in patients with SPG18 suggests that the loss of Erlin-2 function was pathogenic through persistent activation of IP3R and neuronal channels, ${ }^{1}$ and whether this mechanism is also at work in ALS phenotype remains to be investigated.

\section{Study funding}

This study was funded by the Association Française contre les Myopathies (AFM, R16061DD), the Association pour la Recherche sur la Sclérose latérale amyotrophique et autres maladies du motoneurone (ARSla, France, contract R17050DD), the Aide à la Recherche des Maladies du Cerveau association (ARMC, France, contract R16009DD), the Sclérose Latérale Amyotrophique Fondation Recherche (S.L.A.F.R.) and La Longue Route des Malades de la SLA associations (to S.M.) and the Verum Foundation, the French Agency for Research (ANR-13-ISV1-00002), the European commission through the H2020 program (SOLVE-RD), the E-Rare programme (Neurolipid, ANR-13-ERARE-0003-02), and the Strumpell-Lorrain association (to G.S.).

\section{Disclosure}

Disclosures available: Neurology.org/NG.

\section{Publication history}

Received by Neurology: Genetics June 7, 2019. Accepted in final form September 5, 2019. 
Appendix Authors

\begin{tabular}{|c|c|c|c|}
\hline Name & Location & Role & Contribution \\
\hline $\begin{array}{l}\text { Maria-Del-Mar } \\
\text { Amador, MD, } \\
\text { MSc }\end{array}$ & $\begin{array}{l}\text { Sorbonne } \\
\text { University, } \\
\text { France }\end{array}$ & Author & $\begin{array}{l}\text { Analyzed the data and } \\
\text { drafted the manuscript } \\
\text { for intellectual content }\end{array}$ \\
\hline $\begin{array}{l}\text { François } \\
\text { Muratet, MSc }\end{array}$ & $\begin{array}{l}\text { Sorbonne } \\
\text { University, } \\
\text { France }\end{array}$ & Author & $\begin{array}{l}\text { Major role in the } \\
\text { acquisition of data }\end{array}$ \\
\hline $\begin{array}{l}\text { Elisa Teyssou, } \\
\text { PhD }\end{array}$ & $\begin{array}{l}\text { Sorbonne } \\
\text { University, } \\
\text { France }\end{array}$ & Author & $\begin{array}{l}\text { Major role in the } \\
\text { acquisition of data }\end{array}$ \\
\hline $\begin{array}{l}\text { Guillaume } \\
\text { Banneau, PhD }\end{array}$ & $\begin{array}{l}\text { Pitié- } \\
\text { Salpêtrière } \\
\text { Hospital, } \\
\text { Paris, France }\end{array}$ & Author & $\begin{array}{l}\text { Major role in the } \\
\text { acquisition of data }\end{array}$ \\
\hline $\begin{array}{l}\text { Véronique } \\
\text { Danel-Brunaud, } \\
\text { MD, MSc }\end{array}$ & $\begin{array}{l}\text { Lille } \\
\text { University } \\
\text { Hospital, } \\
\text { France }\end{array}$ & Author & $\begin{array}{l}\text { Major role in the } \\
\text { acquisition and analysis } \\
\text { of data }\end{array}$ \\
\hline $\begin{array}{l}\text { Etienne Allart, } \\
\text { MD, PhD }\end{array}$ & $\begin{array}{l}\text { Lille } \\
\text { University } \\
\text { Hospital, } \\
\text { France }\end{array}$ & Author & $\begin{array}{l}\text { Major role in the } \\
\text { acquisition of data }\end{array}$ \\
\hline $\begin{array}{l}\text { Jean-Christophe } \\
\text { Antoine, MD }\end{array}$ & $\begin{array}{l}\text { Saint-Etienne } \\
\text { University } \\
\text { Hospital, } \\
\text { France }\end{array}$ & Author & $\begin{array}{l}\text { Major role in the } \\
\text { acquisition of data }\end{array}$ \\
\hline $\begin{array}{l}\text { Jean-Philippe } \\
\text { Camdessanché, } \\
\text { MD, PhD }\end{array}$ & $\begin{array}{l}\text { Saint-Etienne } \\
\text { University } \\
\text { Hospital, } \\
\text { France }\end{array}$ & Author & $\begin{array}{l}\text { Major role in the } \\
\text { acquisition of data }\end{array}$ \\
\hline $\begin{array}{l}\text { Mathieu } \\
\text { Anheim, MD, } \\
\text { PhD }\end{array}$ & $\begin{array}{l}\text { Strasbourg } \\
\text { University, } \\
\text { France }\end{array}$ & Author & $\begin{array}{l}\text { Major role in the } \\
\text { acquisition of data }\end{array}$ \\
\hline $\begin{array}{l}\text { Gabrielle } \\
\text { Rudolf, PhD }\end{array}$ & $\begin{array}{l}\text { Strasbourg } \\
\text { University, } \\
\text { France }\end{array}$ & Author & $\begin{array}{l}\text { Major role in the } \\
\text { acquisition of data }\end{array}$ \\
\hline $\begin{array}{l}\text { Christine } \\
\text { Tranchant, MD }\end{array}$ & $\begin{array}{l}\text { Strasbourg } \\
\text { University, } \\
\text { France }\end{array}$ & Author & $\begin{array}{l}\text { Major role in the } \\
\text { acquisition of data }\end{array}$ \\
\hline
\end{tabular}

Appendix (continued)

\begin{tabular}{|c|c|c|c|}
\hline Name & Location & Role & Contribution \\
\hline $\begin{array}{l}\text { Marie-Céline } \\
\text { Fleury, MD }\end{array}$ & $\begin{array}{l}\text { Strasbourg } \\
\text { University, } \\
\text { France }\end{array}$ & Author & $\begin{array}{l}\text { Major role in the } \\
\text { acquisition and analysis } \\
\text { of data }\end{array}$ \\
\hline $\begin{array}{l}\text { Emilien } \\
\text { Bernard, MD, } \\
\text { MSc }\end{array}$ & $\begin{array}{l}\text { Lyon } \\
\text { University } \\
\text { Hospital, } \\
\text { France }\end{array}$ & Author & $\begin{array}{l}\text { Major role in the } \\
\text { acquisition and analysis } \\
\text { of data }\end{array}$ \\
\hline $\begin{array}{l}\text { Giovanni } \\
\text { Stevanin, PhD }\end{array}$ & $\begin{array}{l}\text { Sorbonne } \\
\text { University } \\
\text { France }\end{array}$ & Author & $\begin{array}{l}\text { Analyzed the data } \\
\text { and drafted the } \\
\text { manuscript for } \\
\text { intellectual content }\end{array}$ \\
\hline $\begin{array}{l}\text { Stéphanie } \\
\text { Millecamps, } \\
\text { PharmD, PhD }\end{array}$ & $\begin{array}{l}\text { Sorbonne } \\
\text { University } \\
\text { France }\end{array}$ & Author & $\begin{array}{l}\text { Designed and } \\
\text { conceptualized the } \\
\text { study, analyzed the data, } \\
\text { and drafted the } \\
\text { manuscript for intellectual } \\
\text { content }\end{array}$ \\
\hline
\end{tabular}

\section{References}

1. Alazami AM, Adly N, Al Dhalaan H, Alkuraya FS. A nullimorphic ERLIN2 mutation defines a complicated hereditary spastic paraplegia locus (SPG18). Neurogenetics 2011;12:333-336.

2. Al-Saif A, Bohlega S, Al-Mohanna F. Loss of ERLIN2 function leads to juvenile primary lateral sclerosis. Ann Neurol 2012;72:510-516.

3. Yildirim Y, Orhan EK, Iseri SA, et al. A frameshift mutation of ERLIN2 in recessive intellectual disability, motor dysfunction and multiple joint contractures. Hum $\mathrm{Mol}$ Genet 2011;20:1886-1892.

4. Rydning SL, Dudesek A, Rimmele F, et al. A novel heterozygous variant in ERLIN2 causes autosomal dominant pure hereditary spastic paraplegia. Eur J Neurol 2018;25:943.e71.

5. Teyssou E, Chartier L, Amador MD, et al. Novel UBQLN2 mutations linked to amyotrophic lateral sclerosis and atypical hereditary spastic paraplegia phenotype through defective HSP70-mediated proteolysis. Neurobiol Aging 2017;58: 239.e211-239 e220.

6. Morais S, Raymond L, Mairey M, et al. Massive sequencing of 70 genes reveals a myriad of missing genes or mechanisms to be uncovered in hereditary spastic paraplegias. Eur J Hum Genet 2017;25:1217-1228.

7. Tian WT, Shen JY, Liu XL, et al. Novel mutations in endoplasmic reticulum lipid raftassociated protein 2 gene cause pure hereditary spastic paraplegia type 18 . Chin Med J 2016;129:2759-2761.

8. Kollewe K, Mauss U, Krampfl K, Petri S, Dengler R, Mohammadi B. ALSFRS-R score and its ratio: a useful predictor for ALS-progression. J Neurol Sci 2008;275:69-73.

9. Chia R, Chiò A, Traynor BJ. Novel genes associated with amyotrophic lateral sclerosis: diagnostic and clinical implications. Lancet Neurol 2018;17:94-102.

10. Brenner D, Yilmaz R, Müller K, et al. Hot-spot KIF5A mutations cause familial ALS. Brain 2018;141:688-697. 


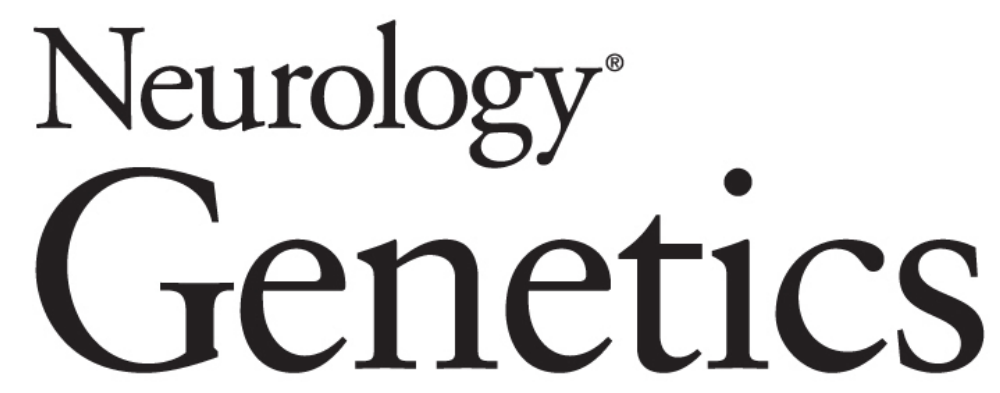

Spastic paraplegia due to recessive or dominant mutations in ERLIN2 can convert to ALS

Maria-Del-Mar Amador, François Muratet, Elisa Teyssou, et al. Neurol Genet 2019;5;

DOI 10.1212/NXG.0000000000000374

This information is current as of November 13, 2019

Neurol Genet is an official journal of the American Academy of Neurology. Published since April 2015, it is an open-access, online-only, continuous publication journal. Copyright Copyright () 2019 The Author(s). Published by Wolters Kluwer Health, Inc. on behalf of the American Academy of Neurology.. All rights reserved. Online ISSN: 2376-7839.

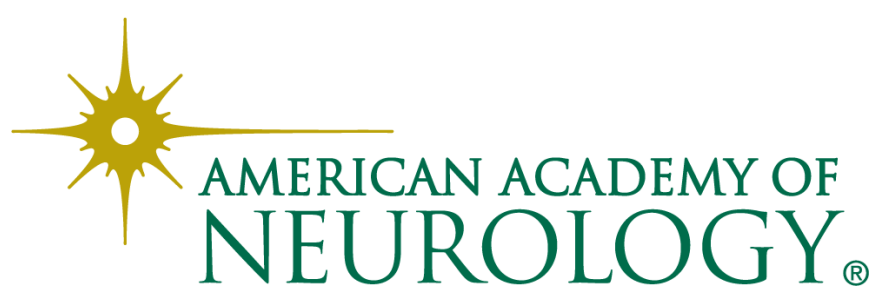




\section{Updated Information \& Services}

References

Citations

Subspecialty Collections

Permissions \& Licensing

Reprints including high resolution figures, can be found at: http://ng.neurology.org/content/5/6/e374.full.html

This article cites 10 articles, 0 of which you can access for free at: http://ng.neurology.org/content/5/6/e374.full.html\#\#ref-list-1

This article has been cited by 1 HighWire-hosted articles: http://ng.neurology.org/content/5/6/e374.full.html\#\#otherarticles

This article, along with others on similar topics, appears in the following collection(s):

All Clinical Neurology

http://ng.neurology.org//cgi/collection/all_clinical_neurology All Genetics

http://ng.neurology.org//cgi/collection/all_genetics

Amyotrophic lateral sclerosis

http://ng.neurology.org//cgi/collection/amyotrophic_lateral_sclerosis_ Spastic paraplegia

http://ng.neurology.org//cgi/collection/spastic_paraplegia

Information about reproducing this article in parts (figures,tables) or in its entirety can be found online at:

http://ng.neurology.org/misc/about.xhtml\#permissions

Information about ordering reprints can be found online: http://ng.neurology.org/misc/addir.xhtml\#reprintsus

Neurol Genet is an official journal of the American Academy of Neurology. Published since April 2015, it is an open-access, online-only, continuous publication journal. Copyright Copyright $\odot 2019$ The Author(s). Published by Wolters Kluwer Health, Inc. on behalf of the American Academy of Neurology.. All rights reserved. Online ISSN: 2376-7839.

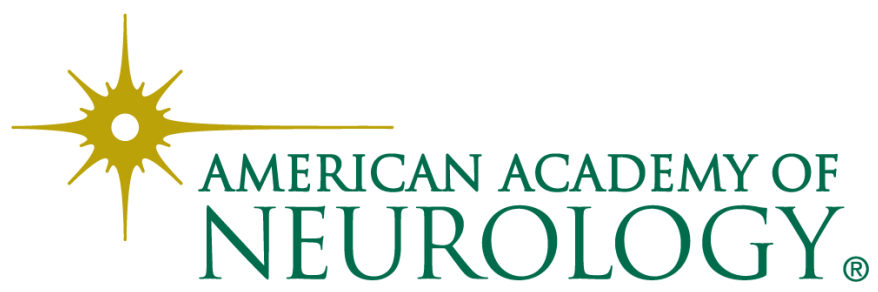

